\title{
CD4 regulatory T cells Control CD8 T cell responses to human Herpesvirus 8 lytic and latency proteins
}

\author{
Lauren Lepone*, Giovanna Rappocciolo, Paolo Piazza, Mariel Jais, Frank J Jenkins, Charles R Rinaldo \\ From 13th International Conference on Malignancies in AIDS and Other Acquired Immunodeficiencies \\ (ICMAOI) \\ Bethesda, MD, USA. 7-8 November 2011
}

\section{Objectives}

CD8 $\mathrm{T}$ cells are considered to play an important role in controlling human herpesvirus 8 (HHV-8/KSHV) infection. However, these $\mathrm{T}$ cell responses are non-robust compared to other herpesviruses, suggesting that they are under tight regulatory control.

\section{Methods}

Longitudinal PBMC samples were obtained from subjects with various outcomes of HHV-8 infection over many years in the Multicenter AIDS Cohort Study. The PBMC were tested by HLA A*0201 multimer staining specific for memory CD8 T cell epitopes of viral lytic and latency proteins, and polyfunctional flow cytometry to detect HHV8-specific, polyfunctional CD8 T cell populations. The effect of Treg was examined by depleting $\mathrm{CD} 4^{+} \mathrm{CD} 25^{\mathrm{Hi}}$ cells.

\section{Results}

Direct staining of PBMC with multimer MHC I complexes showed a relatively high frequency of circulating, HHV-8 lytic and latency antigen-specific CD8 T cells, but low anti-HHV-8 $\mathrm{T}$ cell polyfunctional reactivity. Removal of Treg enhanced $\mathrm{T}$ cell responses to these HHV-8 epitopes. The frequency of T cells specific for HHV-8 lytic antigens was greater than for latent antigens, and this effect was greater when Treg were removed. Numbers of HHV-8 specific effector memory CD8 $\mathrm{T}$ cells increased and terminally differentiated memory CD8 $\mathrm{T}$ cells decreased over many years of HHV-8 infection. We are currently assessing anti-HHV-

\footnotetext{
* Correspondence: Iml33@pitt.edu

Department of Infectious Diseases and Microbiology, University of Pittsburgh Graduate School of Public Health, Pittsburgh, PA, USA
}

$8 \mathrm{~T}$ cell and Treg activity in relation to development of KS.

\section{Conclusions}

We show for the first time that Treg suppress CD8 T cell responses to HHV-8 lytic and latency antigens, effectively masking more robust, underlying anti-HHV-8 $\mathrm{T}$ cell responses. The involvement of CD8 $\mathrm{T}$ cells and Treg in control of HHV-8 infection has important implications for development of vaccines to prevent KS.

Published: 19 April 2012

doi:10.1186/1750-9378-7-S1-017

Cite this article as: Lepone et al:: CD4 regulatory T cells Control CD8 T cell responses to human Herpesvirus 8 lytic and latency proteins. Infectious Agents and Cancer 2012 7(Suppl 1):017.

Submit your next manuscript to BioMed Central and take full advantage of:

- Convenient online submission

- Thorough peer review

- No space constraints or color figure charges

- Immediate publication on acceptance

- Inclusion in PubMed, CAS, Scopus and Google Scholar

- Research which is freely available for redistribution

Submit your manuscript at www.biomedcentral.com/submit
() Biomed Central 